КРАТКИЕ СООБЩЕНИЯ

\title{
A COMPARATIVE ANALYSIS OF THE CULTURED MICROMYCETES IN OLIGOTROPHIC PEATLANDS OF NATURAL BIOSPHERE RESERVATIONS LOCATED IN THE NORTHERN AND CENTRAL PARTS OF RUSSIA
}

\author{
E. N. Bilanenko'1, O. A. Grum-Grzhimaylo ${ }^{2}$ \\ ${ }^{1}$ Department of Mycology and Phycology, Lomonosov Moscow State University \\ e-mail:e_bilanenko@mail.ru \\ ${ }^{2}$ White Sea Biological Station, Faculty of Biology, Lomonosov Moscow State University \\ e-mail:olgrgr@wsbs-msu.ru
}

Received: 31.03 .2016

\begin{abstract}
The current study addresses the fungal diversity of the peatlands that vary geographically and geologically, in the central and northern parts of Russia. The central (Smolenskaya area, National Park «Smolenskoye Poozerie») and northern (White Sea Biological Station area) peatlands have a different geological history, the former have a glacial origin, while the latter are of marine origin. Our aim was to investigate the fungal biota of these zones full of Sphagnum moss, and possibly reveal the species that are pertinent to these particular habitats.

In both investigated areas, we found an overall poor species diversity with a high fraction of sterile mycelia. Many penicillia species were dominating in all peat samples - P. thomii, P. spinulosum, P. glabrum, P. funiculosum, P. aurantiogriseum (together with Geotrichum candidum), many of them are known to degrade Sphagnum. We were particularly interested in the dynamics of the species from the genus Oidiodendron that have been shown to be involved in primary Sphagnum degradation. The northern area contained a larger species diversity of Oidiodendron, as compared to the central zone. Interestingly, insect-associated species of the genus Tolypocladium and Beauveria, along with the psychrotolerant species of Geomyces and Tolypocladium were recovered only from the northern peatlands. Aspergillus spp. were found in peatlands of the central zone only. We link this result to the climatic features of the area, but also different invertebrate contents that may be utilized by fungi. We detected a tendency of an increasing diversity of Oidiodendron species, psychrotolerant and entomopathogenic fungal species as well as a proportion of sterile forms in the northern area.
\end{abstract}

Key words: entomopathogenic fungi, fungi decomposing Sphagnum, fungi in peatlands, micromycetes in peatlands, Oidiodendron spp., psychrotolerant fungi, Tolypocladium spp.

Oligotrophic peatlands cover more than $10 \%$ of Russia's territory and are the largest reservoirs of peat among peatland types in Russia (Yurkovskaya, 2004). Although oligotrophic peatlands are prevalent in northern areas such as taiga and tundra zones, they also occur more southerly, to the extent of the steppe zone. The peat accumulation is caused by microorganisms that decompose organic matter at a relatively slow rate. The slow rate is corroborated by extremely unfavourable abiotic conditions: low oxygen, low temperature, low $\mathrm{pH}$, high humidity and presence of inhibitory phenolic compounds from a local vegetation, mostly Sphagnum mosses. Specific groups of fungi and bacteria are the main players involved in the process of organic matter decomposition in peat(Kachalkin etal., 2005; Gilbert, Mitchell, 2006; Thormann, Rice, 2007; Andersen et al., 2010; Golovchenko et al., 2013). However, the diversity of fungi inhabiting oligotrophic peatland remains understudied, especially in the northern regions. The comparison of the fungal biota between oligotrophic peatlands of both central and northern areas would allow to evaluate the fungal species that are shared (or different) among habitats, possibly shedding some light on their physiology in peat. Existing studies suggest that the fungal diversity among oligotrophic peatlands may vary significantly (Thormann et al., 2004; Thormann, Rice, 2007). The reason is believed to be the unique associations of fungi with specific plants, which are pertinent to a given area (Nilsson et al., 1992; Thormann et al., 2004; Filippova, 2015).

\section{Material and Methods}

We have been monitoring fungi at the White Sea coastal and Smolensk region peatlands for a number of years now. Using various approaches, we sought to recover most of the culturable fungal species from that area (Bilanenko, Grum-Grzhimaylo, 2007; Grum-Grzhimaylo et al., 2010, 2012, 2016). Since 
the Sphagnum mosses are the main ingredient of peat, we collected and analyzed the samples from the vertical columns of peat deposits where dominated by Sphagnum spp. Hence, our comparative analysis of the fungal biota in differently located oligotrophic peats was accounting for the climatic factors (mainly temperature) rather than plant-associated differences of fungal communities. The $\mathrm{pH}$ values of the samples in both regions were similar and varied from 4.0 to 4.5 . Climatic factors globally affect the distribution of biota, including one of the most prominent inhabitants of the oligotrophic peats - an arctic mosquito (Aedes spp., Culex spp.). During warm season, these species reproduce in bulk, and along with the plant material, can act as a food source for fungi (Bubnova et al., 2014). Our research attempts to compare fungal diversity of the two distinct following types of peatlands - the White Sea coastal peatlands (White Sea Biological Station, WSBS, northern, $66^{\circ} 34^{\prime} \mathrm{N}, 33^{\circ} 08^{\prime} \mathrm{E}$ ) and the Smolensk region peatlands (National Park «Smolenskoye Poozerie», SP, central, 55 53' N, $31^{\circ} 40^{\prime} \mathrm{E}$ ) (Fig.). The first type appears to have been formed as a result of a part of the sea becoming isolated in the course of a land uplift, followed by both demineralization and bogging (Shaporenko et al., 2005; Pantyulin, Krasnova, 2011), whereas the central type shows boggy depressions of glacial origin (Smolensk LakeLand..., 2016). The comparison of the fungal biota between the two boggy areas may give us a clue about the shared species, but also unique ones that may contribute to local ecology of a given peatland.

The climate of the SP is moderately continental with well-defined seasons. Wet air masses from the Atlantic release frosts and snowfalls in winter and a high temperature and rain in summer. The average yearly temperature here is about $4.3^{\circ} \mathrm{C}$ (National Park..., 2016). The climate of the WSBS region is transitional from marine polar to moderately continental. There are long winter and spring, short summer and long autumn at the WSBS. The average yearly temperature here is about $0.5^{\circ} \mathrm{C}$ (Shilovtseva, 2009). In June 200629 and 25 peat samples from three SP peatlands were taken and from three WSBS peatlands in June 2007, subsequently. The detailed description of the peatlands and taking, storing and cultivation of the samples has been exposed in our earlier works (Bilanenko, Grum-Grzhimaylo, 2007; Grum-Grzhimaylo et al., 2016). Only the differences in the methods are remarked here. The peat samples from the SP were stored at deep freeze until the cultivation, whereas the samples from the WSBS

\section{Results and Discussion}

Our results indicate that the explored peatlands of both regions show low species diversity of the cultured micromycetes. The analysis of the SP

\section{RUSSIA}

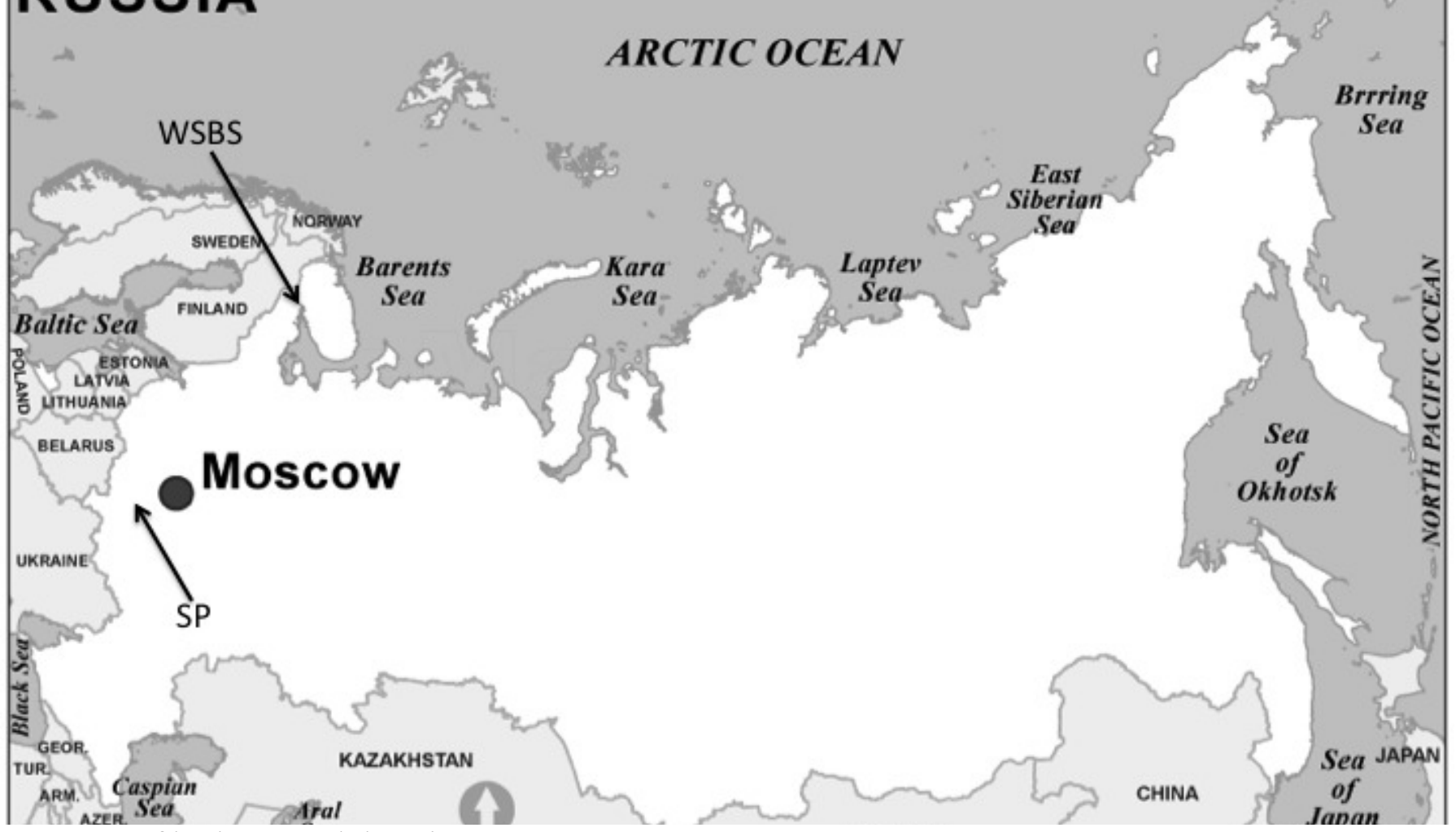

Fig. Map of both research locations. 
samples helped to identify 39 species of fungi and to reveal 3 sterile isolates. The samples of the WSBS peatlands contained 31 species and 8 sterile mycelia. Only 8 fungal species were found in both regions (sterile isolates excluded) (Table). It is known that specific conditions of peatlands restrict the diversity of fungi (Grum-Grzhimaylo, Bilanenko, 2010).

The prevailing number of anamorphic species belonged to Ascomycota, mostly Penicillium spp. These results do not disprove the existing view on the mycobiota of peatlands (Thormann, Rice, 2007). The following species were found in both regions: $P$. thomii, P. spinulosum, P. glabrum, $P$. funiculosum, $P$. aurantiogriseum. The capacity of $P$. spinulosum and $P$. thomii to decompose Sphagnum was mentioned in a number of earlier mycological works (Chastuchin, 1967; Dickinson, Maggs, 1974). P. spinulosum is regarded as a typical species for a humus soil horizon and oligotrophic peatlands (Summerbell, 2005). This species is widely spread in the soils of tundra and taiga and in bogs of various types. $P$. spinulosum is capable to grow in a wide range of temperatures (from $5^{\circ} \mathrm{C}$ to $42^{\circ} \mathrm{C}$ ). The upper layers of peatlands, including the peatlands of temperate zones, are characterized by drastic changes in temperature regime. P. thomii is capable to develop in the temperature range of $5-37^{\circ} \mathrm{C}$. It is found in all complexes of filamentous fungi isolated from acidic soils, in peatlands and from bog plants (Domsh et al., 2007). P. glabrum is a common species in podsolic and other acidic soils, raised bogs and fens. P. glabrum is widely spread in northern regions, including the soils of the Arctic tundra (Nilsson et al., 1992; Domsh et al., 2007). In our research this species was found in two WSBS peatlands and in one SP peatland. The cosmopolitan species $P$. funiculosum (Talaromyces funiculosus) was among the dominating species in all SP peatlands (frequency of occurrence was up to $20-30 \%$ and the colony-forming units (CFU) value up to $10^{4} \mathrm{CFU}$ per 1 gram of a dry sample). P. funiculosum was found in all WSBS peatlands and dominated in one of them (frequency of occurrence up to $100 \%$, CFU value up to $10^{6} \mathrm{CFU}$ per 1 gram of a dry sample). $P$. funiculosum can grow in a broad temperature range $\left(5-42^{\circ} \mathrm{C}\right)$. This species survives in extremely cold and acidic conditions, in low oxygen conditions (Domsh et al., 2007; Grum-Grzhimaylo, 2013). It can be found in all types of soils, in oligotrophic peatlands and in taiga marsh soils. P. funiculosum is capable to destroy Sphagnum mosses (Dickinson, Maggs, 1974; Thormann et al., 2004; Thormann, Rice, 2007).
We found Geotrichum candidum (Diplodascus geotrichum) in both peatland systems mentioned in this work. This fungus is also known as a destructor of Sphagnum mosses (Dickinson, Maggs, 1974; Karunen, Kalviainen, 1985). It can exist in highly moist conditions (Dix, Webster, 1995). In further research we managed to isolate it in all WSBS peatlands samples we explored.

Oidiodendron species are known as primary destructors of Sphagnum mosses (Tsuneda et al., 2001). Oidiodendron spp. grow at acidic and even extremely acidic conditions ( $\mathrm{pH}$-values from 1.5 to 6.0) (Gross, Robbins, 2000; Domsh et al., 2007). In our research $O$. griseum and $O$. periconioides were found in northern peatlands, $O$. cereale was found in peatlands of the central zone. O. griseum was one of the dominant species in WSBS peatlands. O. griseum is a typical species of the ericales rhizosphere, peat and podsolic soils. $O$. periconioides and $O$. cereale are also known as typical species for Sphagnum bogs (Thormann, Rice, 2007). In frost peatlands of the Kola Peninsula we discovered even greater Oidiodendron species diversity than in WSBS peatlands (our unpublished data).

The psychrotolerant species Geomyces pannorum (Pseudogymnoascus pannorum) was identified in WSBS samples with high frequency and abundance. However, it was not revealed in SP samples at all. G. pannorum is a psychrotolerant species and it can be found predominantly in northern soils of tundra and in conditions of the natural cryopreservation (Tosi et al., 2002; Kochkina et al., 2007). This species is known as polyextremotolerant, capable to develop under the influence of numerous stress factors such as low temperature, low water activity and lack of oxygen. This allowed it to survive in anaerobic conditions, which are common for cryopegs in permafrost (Kochkina et al., 2007; Shcherbakova et al., 2010). G. pannorum can grow in a wide range of $\mathrm{pH}$ values (3.5-8.0) (van Oorschot, 1980). This species was isolated in large quantities (CFU value up to $10^{5}$ for 1 gram of a dry sample) at the depth of 1 metre from a peat sample of a northern bog, which supports the conditions of low temperatures and low oxygen content. Psychrotolerant type of temperature adaptation is also common for Tolypocladium spp. (Bisset, 1982). Tolypocladium spp. were found in the WSBS samples, but not in the SP ones.

Tolypocladium spp. and Beauveria spp. (T. inflatum, T. geodes, B. bassiana) are known as associated with insects. These species were found in the northern peatlands only. This fact was also 
Table. Fungal species isolated from the peatlands (№№ 1, 2, 3). SP - the National Park «Smolenskoye Poozerie». WSBS - the White Sea Biological Station. Common species for SP and WSBS are in boldface

\begin{tabular}{|c|c|c|c|c|c|c|}
\hline \multirow{2}{*}{ Species } & \multicolumn{3}{|c|}{ SP } & \multicolumn{3}{|c|}{ WSBS } \\
\hline & 1 & 2 & 3 & 1 & 2 & 3 \\
\hline Acrodontium crateriforme (J.F.H. Beyma) de Hoog & - & - & - & + & - & - \\
\hline Alternaria alternata (Fr.) Keissl. & - & + & - & + & - & - \\
\hline Aureobasidium pullulans (de Bary \& Löwenthal) G. Arnaud & + & + & + & + & - & - \\
\hline Aspergillus fischeri Wehmer & - & + & - & - & - & - \\
\hline Aspergillus fumigatus Fresen. & - & + & - & - & - & - \\
\hline Aspergillus niger Tiegh. & + & - & - & - & - & - \\
\hline Beauveria bassiana (Bals.-Criv.) Vuill. & - & - & - & - & + & - \\
\hline Botrytis cinerea Pers. & - & - & - & + & - & + \\
\hline Cadophora fastigiata Lagerb. \& Melin & + & - & - & - & - & - \\
\hline Cladosporium cladosporioides (Fresen.) G.A. de Vries & - & - & - & + & - & + \\
\hline Cladosporium herbarum (Pers.) Link & - & - & - & + & + & + \\
\hline Clonostachys rosea (Link) Schroers, Samuels, Seifert \& W. Gams & + & - & - & - & - & - \\
\hline Diplodascus geotrichum (E.E. Butler \& L.J. Petersen) Arx & + & + & - & + & - & - \\
\hline Gibellulopsis nigrescens (Pethybr.) Zare, W. Gams \& Summerb. & - & - & - & + & - & - \\
\hline Lecanicillium evansii Zare \& W. Gams & + & - & - & - & - & - \\
\hline Lecanicillium sp. & - & - & - & - & + & - \\
\hline Mucor hiemalis Wehmer & + & + & + & - & - & - \\
\hline Mucor plumbeus Bonord. & + & - & - & - & - & - \\
\hline Oidiodendron cereale (Thüm.) G.L. Barron & + & - & - & - & - & - \\
\hline Oidiodendron griseum Robak & - & - & - & + & + & - \\
\hline Oidiodendron periconioides Morrall & - & - & - & - & + & - \\
\hline Paecilomyces divaricatus (Thom) Samson, Houbraken \& Frisvad & - & + & + & - & - & - \\
\hline Penicillium aurantiogriseum Dierckx & + & + & + & - & + & - \\
\hline Penicillium brevicompactum Dierckx & - & - & - & + & + & - \\
\hline Penicillium chermesinum Biourge & + & - & - & - & - & - \\
\hline Penicillium citreonigrum Dierckx & - & - & - & + & + & - \\
\hline Penicillium citrinum Thom & - & + & - & - & - & - \\
\hline Penicillium dierckxii Biourge & + & + & + & - & - & - \\
\hline $\begin{array}{l}\text { Penicillium dipodomyis (Frisvad, Filt. \& } \\
\text { Wicklow) Banke, Frisvad \& S. Rosend. }\end{array}$ & + & + & - & - & - & - \\
\hline Penicillium glabrum (Wehmer) Westling & + & - & - & + & + & - \\
\hline Penicillium implicatum Biourge & - & - & - & - & - & + \\
\hline Penicillium lividum Westling & - & + & - & - & - & - \\
\hline Penicillium nalgiovense Laxa & - & - & - & - & + & - \\
\hline Penicillium oxalicum Currie \& Thom & - & + & - & - & - & - \\
\hline Penicillium purpurascens (Sopp) Biourge & + & - & - & - & - & - \\
\hline Penicillium restrictum J.C. Gilman \& E.V. Abbott & - & - & - & + & - & - \\
\hline Penicillium rolfsii Thom & - & - & - & - & + & - \\
\hline Penicillium spinulosum Thom & + & + & + & + & + & + \\
\hline Penicillium thomii Maire & - & + & - & + & + & + \\
\hline Penicillium velutinum J.F.H. Beyma & + & - & - & - & - & - \\
\hline Penicillium vinaceum J.C. Gilman \& E.V. Abbott & - & - & - & + & + & + \\
\hline Penicillium waksmanii K.M. Zaleski & + & + & - & - & - & - \\
\hline Pseudogymnoascus pannorum (Link) Minnis \& D.L. Lindner & - & - & - & + & - & - \\
\hline Phialophora europaea de Hoog, Mayser \& Haase & - & + & - & - & - & - \\
\hline Rhizopus stolonifer (Ehrenb.) Vuill. & + & - & - & - & - & - \\
\hline Sclerotinia sp. & - & - & - & + & + & - \\
\hline
\end{tabular}


The end of a Table

\begin{tabular}{|c|c|c|c|c|c|c|}
\hline \multirow{2}{*}{ Species } & \multicolumn{3}{|c|}{ SP } & \multicolumn{3}{|c|}{ WSBS } \\
\hline & 1 & 2 & 3 & 1 & 2 & 3 \\
\hline $\begin{array}{l}\text { Talaromyces aculeatus (Raper \& Fennell) } \\
\text { Samson, N. Yilmaz, Frisvad \& Seifert }\end{array}$ & - & + & - & - & - & - \\
\hline Talaromyces diversus (Raper \& Fennell) Samson, N. Yilmaz \& Frisvad & - & - & - & - & + & - \\
\hline Talaromyces funiculosus (Thom) Samson, N. Yilmaz, Frisvad \& Seifert & + & + & + & - & + & + \\
\hline $\begin{array}{l}\text { Talaromyces purpureogenus Samson, Yilmaz, Houbraken, } \\
\text { Spierenb., Seifert, Peterson, Varga \& Frisvad }\end{array}$ & + & - & - & - & - & - \\
\hline Talaromyces rugulosus (Thom) Samson, N. Yilmaz, Frisvad \& Seifert & + & - & - & - & - & - \\
\hline Talaromyces variabilis (Sopp) Samson, N. Yilmaz, Frisvad \& Seifert & + & + & - & - & - & - \\
\hline $\begin{array}{l}\text { Talaromyces verruculosus (Peyronel) Samson, } \\
\text { N. Yilmaz, Frisvad \& Seifert }\end{array}$ & - & - & - & + & - & - \\
\hline Thyronectria cucurbitula (Tode) Jaklitsch \& Voglmayr & - & - & - & + & - & - \\
\hline Tolypocladium geodes W. Gams & - & - & - & - & + & - \\
\hline Tolypocladium inflatum W. Gams & - & - & - & + & - & - \\
\hline Trichoderma koningii Oudem. & - & - & + & - & - & - \\
\hline Umbelopsis ramanniana (Möller) W. Gams & + & - & - & - & - & - \\
\hline Sterile isolates (12 morphotypes) & 3 & - & - & 3 & 5 & 1 \\
\hline
\end{tabular}

demonstrated in our later works (Grum-Grzhimaylo et al., 2016). One of the possible reasons for such abundance of Tolypocladium spp. and B. bassiana in the northern peatlands may be connected with considerable populations of invertebrates, including larvae of sanguivorous mosquitoes, on which these species can grow.

Aspergillus spp. (A. fischeri, A. fumigatus, A. niger) known as typical in the southern regions were found in SP peatlands only.

A considerable share in fungi societies of both regions is represented by sterile mycelia. Their number is higher in northern regions. Using molecular methods we showed later that the majority of sterile forms are basidiomycetes (GrumGrzhimaylo et al., 2016).

The fact is that the absence of some species in the samples could be explained by the low number of samples or by other methodological errors. For example, the absence of Trichoderma spp. in WSBS samples was quite surprising. In the following years we consistently discovered $T$. piluliferum, T. polysporum, T. harzianum, T. viride in WSBS peatlands.

We assume that the detected tendency of the increasing diversity and the abundance of Oidiodendron spp., psychrotolerant and entomopathogenic fungal species (Geomyces pannorum, Tolypocladium spp., Beauveria spp.) as well as the proportion of sterile forms in the northern area is clear.

\section{Acknowledgements}

The work was supported by the research grant RFBF No. 15-29-02553 and RSF grant No. 14-50-00029 (the cultivation and collection of the fungi, Grum-Grzhimaylo; identification of fungi, Bilanenko). The work on collecting samples of peatlands was supported by the Program of Government jobs, parts 2 no. 0110 (№ AAAA-A16-116021660088-9).

\section{References}

Andersen R., Grasset L., Thormann M.N., Rochefort L., Francez A.-J. 2010. Changes in microbial community structure and function following Sphagnum peatland restoration. Soil Biology and Biochemistry 42: 291-301.

Bilanenko E.N., Grum-Grzhimaylo O.A. 2007. Microfungi of the boggy areas of the National Park «Smolenskoye Poozerie». In: Historical and cultural heritage and natural diversity: the experience of protected areas. Smolensk: Smolenskaya gorodskaya tipografiya. P. 25-41. [In Russian]

Bisset J. 1982. Notes on Tolypocladium and related genera. Canadian Journal of Botany 61: 1311-1329.

Bubnova E.N., Grum-Grzhimaylo O.A., Konovalova O.P., Marfenina O.E. 2014. Fifty years of mycological studies at the White Sea Biological Station of Moscow State University: Challenges, results, and outlook. Moscow University biological sciences bulletin 69 (1): 23-39.

Chastuchin V.Ya. 1967. Decomposition of plant mosses by fungi. Mikologia i Fitopatologia 1: 294-308. [In Russian]

Dickinson C.H., Maggs G.H. 1974. Aspects of the decomposition of Sphagnum leaves in an ombrophilous mire. New Phytol. 73 (6): 1249-1257.

Dix N.J., Webster J. 1995. Aquatic fungi. In: Fungal Ecology. London: Chapman \& Hall. P. 225-283.

Domsch K.H., Gams W., Anderson T.H. 2007. Compendium of soil fungi. 2nd edition revised by W. Gams. Eching: IHW. $700 \mathrm{p}$. 
Filippova N.V. 2015. On the communities of fungi of raised bogs in taiga belt of Western Siberia II. Microfungi on plant litter. Mikologiya i fitopatologiya 49 (2): 114-122 [In Russian].

Gilbert D., Mitchell E.A.D., Martini I.P., Martínez-Cortizas A., Chesworth W. 2006. Microbial diversity in Sphagnum peatlands. In: Peatlands: Evolution and Records of Environmental and Climate Changes. Amsterdam: Elsevier. P. 287-318.

Golovchenko A.V., Kurakov A.V., Semenova T.A., Zvyaginzev D.G. 2013. Abandance, diversity, viability, and factorial ecology of fungi in peatbogs. Eurasian Soil Science 46 (1): 74-90.

Gross S., Robbins E.I. 2000. Acidophilic and acid-tolerant fungi and yeasts. Hydrobiologia 433: 91-109.

Grum-Grzhimaylo O.A. 2013. Micromycetes of boggy ponds of Kandalaksha Bay at the White Sea coast. $\mathrm{PhD}$ Thesis. Moscow: Moscow State University. 236 p. [In Russian]

Grum-Grzhimaylo O.A., Bilanenko E.N. 2010. Micromycetes as a component of ecosystem of peatbogs. Mikologiya $i$ fitopatologiya 44 (6): 485-496. [In Russian]

Grum-Grzhimaylo O.A., Bilanenko E.N. 2012. Complexes of micromycetes in peatbogs of Kandalaksha Bay at the White Sea coast. Mikologiya i fitopatologiya 46 (5): 297305. [In Russian]

Grum-Grzhimaylo O.A., Debets A.J.M., Bilanenko E.N. 2016. The diversity of microfungi in the boggy areas originated from the White Sea. Mycologia 108: 233-254.

Smolensk LakeLand in Russia. 2016. Available at: http:// reserves-park.ru/natsionalnye-parki-rossii/78smolenskoe-poozere.html [Accessed 27.05.2016].

National Park «Smolensk LakeLand». 2016. Available at: http://www.poozerie.ru [Accessed 27.05.2016].

Kachalkin A.V., Chernov I.Yu., Semyonova T.A., Golovchenko A.V. 2005. Characteristic of the taxonomy structure hyphomycetes and yeast communities in peat soils of different genesis. Mat. IV nauch. konf. Bolota i Biosphera. Tomsk, P. 208-216. [In Russian]

Karunen P., Kalviainen E. 1985. Senescence and post-mortem changes in the ultrastructure of Sphagnum fuscum (Klinggr.) Schleich leaf cells. New Phytol. 100: 419-427.

Kochkina G.A., Ivanushkina N.E., Akimov V.N., Gilichinskii D.A., Ozerskaya S.M. 2007. Halo- and psychrotolerant Geomyces fungi from arctic cryopegs and marine deposits.
Microbiology 76 (1): 31-38.

Nilsson M., Bååth E., Söderström B. 1992. The microfungal communities of a mixed mire in northern Sweden. Canadian Journal of Botany 70 (2): 272-276.

van Oorschot C.A.N. 1980. A revision of Chrysosporium and allied genera. Studies in Mycology 20: 89 [Baarn: Centraalbureau voor Schimmelcultures].

Pantiulin A.N., Krasnonva E.D. 2011. Otdelyaushiesya vodoemi Belogo moray: noviy objekt dlya mezhdisciplinarnih issledovaniy. In: Mat. XIX Mezhdunarodnoy nauch. konf. (shkoli) po morskoy geologii «Geologia morey I okeanov». Moscow. P. 241-245. [In Russian]

Rice A.V., Currah R.S. 2005. Oidiodendron: A survey of the named species and related anamorphs of Myxotrichum. Studies in Mycology 53: 83-120.

Shaporenko S.I., Koreneva G.A., Pantyulin A.N., Pertsova N.M. 2005. Characteristics of the ecosystems of water bodies separating from Kandalaksha Bay of the White Sea. Water Resources 32 (5): 469-483. [In Russian]

Shcherbakova V.A., Kochkina G.A., Ivanushkina N.E. Laurinavichius K.S., Ozerskaya S.M., Akimenko V.K. 2010. Growth of the fungus Geomyces pannorum under anaerobiosis. Microbiology 79 (6): 845-848.

Shilovtseva O.A., Romanenko F.A. 2009. Air temperature changes at White Sea shores and islands in the $19^{\text {th }}$ and $20^{\text {th }}$ centuries. In: Global climatology and ecodynamics. Anthropogenic changes to Planet Earth. Chichester. UK: Springer. P. 301-330.

Summerbell R.C. 2005. Root endophyte and mycorrhizosphere fungi of black spruce, Picea mariana, in a boreal forest habitat: influence of site factors on fungal distributions. Studies in Mycology 53: 121-145.

Thormann M.N., Currah R.S., Bayley S.E. 2004. Patterns of distribution of microfungi in decomposing bog and fen plants. Canadian Journal of Botany 82 (5): 710-720.

Thormann M.N., Rice A.V. 2007. Fungi from peatlands. Fungal Diversity 24: 241-299.

Tosi S., Casado B., Gerdol R., Caretta G. 2002. Fungi isolated from Antarctic mosses. Polar Biology 25: 262-268.

Tsuneda A., Thormann M.N., Currah R.S. 2001. Modes of cellwall degradation of Sphagnum fuscum by Acremonium cf. curvulum and Oidiodendron maius. Canadian Journal of Botany 79: 93-100.

Yurkovskaya T.K. 2004. Raised bogs on the north-east of Europe. Annali di Botanika nuova serie IV: 19-28. 